\title{
Determinants of Equity Share Price Movement: Evidence From the Nigerian Banking Industry (2000 - 2014)
}

\author{
Akan David Chucks ${ }^{1}$, Ighosewe Enaibre Felix ${ }^{1} \&$ Sunny Oteteya Temile ${ }^{1}$ \\ ${ }^{1}$ Department of Accounting, Banking and Finance, Delta State University, Asaba Campus, Delta State, Nigeria \\ Correspondence: Akan David Chucks, Department of Accounting, Banking and Finance, Delta State University, \\ Asaba Campus, Delta State, Nigeria.
}

Received: April 11, 2020

Accepted: May 19, 2020

Online Published: January 9, 2021

doi:10.5430/ijfr.v12n1p319

URL: https://doi.org/10.5430/ijfr.v12n1p319

\begin{abstract}
Profit maximization is the primary focus of investors. The banking industry is a veritable sector for investment, however, understanding the determinants of profitability is paramount as it assists investors to know where their money should go. This study, therefore, investigates the influence that Earnings per share (EPS) and Non-Financial factors namely: inflation, exchange rate, and interest rate have on share price movement. The Ex-post factor was adopted as the research design. The data on EPS was collected from the Central Bank of Nigeria (CBN), Factbook, and the financial reports of the selected banks. The data on the Interest rate, Inflation, and Exchange Rate were collected from the Bulletin of CBN. The time-series data were diagnosed using the Unit root test; they were detrended where necessary to avoid a spurious result. The data were then analyzed using multiple regression. Also, Variance inflation factors (VIF) were engaged to test for the multicollinearity of the selected variables; while a heteroskedasticity test was carried out for a result free of heteroskedasticity. The outcome from the analysis displayed a positive but insignificant relationship between EPS and the market price of shares (MPS;); The study also revealed a negative and significant relationship between Inflation share price; while Interest Rate is insignificantly and negatively influencing the share price. Finally, Exchange Rate showed a significant influence on the share price. The researcher, therefore, recommends among others the need for Nigerian listed Banks to endeavor to improve on their EPS as this will increase their share price even though it won't be significant. Inflation displayed a negative and significant effect on the share prices of the quoted Banks in Nigeria; policies that will reverse the geometric rise in the inflation presently experienced in Nigeria should be enacted by the Government.
\end{abstract}

Keywords: equity share price, earnings per share, inflation, interest rate and exchange rate

\section{Introduction}

The trend where investors believe so much in investing in shares and stocks appears to be dwindling as the years pass. A stock worth is a symbol of what investors believe a compound is valued and it is often best drawn by the amendment in its measure, that is, the variation in the net present value of its expected future money flows (ICAEW, 2000). The worth of a share quoted within the securities market may be a reflection of the many endogenous (intrinsic) and exogenous (extrinsic) variables referred to as fundamentals, that generally are measurable whereas others stay the merchandise of non-quantifiable human behavior (Omoyiola \& Adeolu, 2011). Additionally, the worth of a stock does not solely reflect a company's current value, it additionally reflects the investor's expectations of future growth and earnings.

Before the 2008 financial crisis, the Nigerian capital market had remained illiquid and experienced a descent in the share prices of corporate organizations, which in turn resulted in long-term investors becoming less interested in investing in the stock market (Onoh, 2002). Due to the aforementioned, organizations pursued improving performance and the establishment of worth with regards to additional wealth for their shareholders and improve on the satisfaction of their customers with other stakeholders. To attain this undertaking, they employed different types of performance management systems. As a result, recent decades have seen a glut of new management approaches for improving organizational performance. These approaches have not worked in all cases as posited by Koller (1994). He maintains further that "the cause of failure was often performance targets that were unclear or not properly aligned with the ultimate goal of creating value". Echebarria-Miguel \& Barrutia-Legarreta (1999) further buttress Kolller's view; they described the unsuccessful management approaches as fractional approaches to business 
realities. That is why they have ceased to meet the current expectation in a world where the organizational environment has become progressively more complex.

Many of the preceding studies, try to see how financial the variables such as EPS, NBVPS, etc influence the performance s of businesses. However, Osisanwo, Bukola, Atanda \& Akinwande (2012) suggested the introduction of external factors or what can be noted as the non-financial factors into the equation as performance indicators to study.

EPS is a well-known variable for measuring performance. The other financial variables used in this study as control are NAVPS and PE ratio. While the non-financial variables adopted are the exchange rate, inflation, and interest rate.

Equity Share according to Brian, 2011, are the shares that do not have preferential privileges with regards to yearly dividends, it does not also have the right of payment of the investment sum in the case of company dissolution.

\subsection{Share Price Determination}

Determining the value of a share is a conflicting task. Economic theory posits that any asset is usually determined by market forces. Moreover, some empirical studies evaluated the connection between certain factors and the stock value. Kang \& Stutz, (2007) examined the determinants of Japanese firm stock price performance covering 1990 to 1993. It was revealed that firms with higher bank loans in 1989 had a worse performance from 1990 to 1993.

\subsection{Earnings Per Share (EPS)}

Quoted companies are required to report on their income statement their computed EPS (Valix \& Peralta, 2009). Pertinent evidence is provided to shareholders this empowers them to take investment decisions critically appraising the historical economic performance and to project utilizing forecast into its future performance. EPS provides such critical information to shareholders. Companies that exhibit the potentials of long-term earnings have the potential of attracting investor's patronage which could result in an upswing in the worth of their share following the law of demand and supply.

\subsection{Inflation}

Shukairi, Waleed, AbdulBaset \& Marwan, (2012) defines inflation as the lasting upsurge in the aggregate price level implying a diminishing of the acquiring ability of cash resulting in the rise of the cost of living. The definition of inflation suggests that the increase in the general price level must be permanent to be seen as inflation. The occurrence of inflation draws the attention of the developed and developing nation. Moreover, Shukairi, Waleed, AbdulBaset \& Marwan (2012), posited that the inflation that occurred in the Jordanian economy was a consequence of the Government's monetary and fiscal policy. Inflation therefore can affect prices and thus may also affect performance.

\subsection{Interest Rate}

According to Victor, Jonathan \& Anthony, 2013 interest rate is a major veritable tool for the control of inflation. He presents interest as the cost paid for the use of another person's money. Again, they affirm that interest rate could affect share price:

\subsection{Exchange Rate}

A good example of a conversation rate is a dollar to N460 Nigerian Naira. It is the expression of the home currency's quotation vis-à-vis foreign ones. Considering the exchange rate from a somewhat diverse viewpoint, the free movement of the conversation rate can turn out to be the fastest moving price in the economy, encapsulating all the foreign goods with it. (http://economicswebinstitute.org/glossary/exchrate.htm).

\section{Statement of the Problem}

Several scholars have revealed that markets largely react when financial information is available to investors (Aduda \& Chemarum, 2010). Investors, therefore, desire concrete information that could inform their judgment and decisions on investment in shares. This need has moved authors to try to posit and analyze certain ways that investors could make better decisions.

The possible connection that exists between the indicators of the capital market and macroeconomic variables has previously been in contention among financial researchers as indicated by Osisanwo \& Atanda, 2012; Obinwogu, 2012; Maku \& Atanda, 2009; Omole, 1999 and Ikoku, 2007. These authors maintain that the worth of stocks is influenced by certain macroeconomic variables. These variables include exchange rate, interest rate, money supply, and even inflation. As revealed by certain empirical studies, investors believe that certain macroeconomic variables as determined by the monetary policy can significantly influence the impulsiveness of the stock values. The 
decisions of investors can be influenced by certain macroeconomic variables (Chritopher, Mminsoo, Huahwa \& Jun, 2006). The Nigerian Government sets macroeconomic performance target every fiscal year which are usually tied to both the fiscal and monetary policies (Omole, 1999). Certain policies have been promulgated by the Central bank of Nigeria to stabilize the macroeconomic variables that they view as having a control on the capital market with a view of increasing performance, promote price stability, stabilize the conversation rate, moderate inflation, and create employment (Omole, 1999). The Nigerian financial regulators overseeing capital markets among other duties are continuously putting in place certain policies to ensure the protection of investors against fraud, (Onoh, 2002).

The performance of the Nigerian Brewery industry is influenced by several factors, including interest rate, inflationary rate, and others. The policies by CBN and other regulatory bodies are not left out. (Inyiama and Chike, 2014) Also, Osisanwo \& Akinwande (2012) and Jimoh, (2009) disclosed that apart from financial ratios, there are other non-financial otherwise referred to as external factors that influence the changes in the worth of stocks. It proposed external or non-financial variables such as inflation rate, interest rate, and the exchange rate that can influence stock price movement significantly. However, there was a dissimilar result with the study conducted by Victor, Jonathan, \& Anthony, (2013). In their study, the Interest rate was not a determining factor of changes in the share price movement; instead, inflation was.

The research by Ike-Ekweremadu (2014) is of particular interest. The study investigated corporate performance indicators aiming at determining their bearing on the changes of the Nigerian Brewery industry's ordinary share price. He evaluated NAVPS, Price-earnings Ratio, and EPS, and the influence they bare on the changes in the share price of the Nigerian Brewery industry. The period covered was thirteen years i.e 2000 to 2012 . The result from the multiple regression revealed that Earnings per share only influenced the share price majorly.

This study takes a cue from the study of Ike-Ekweremadu (2014) intending to bring in external factors. These factors are Interest rate, Exchange rate, and inflation rate. This is in line with Osisanwo, Bukola, Atanda \& Akinwande (2012) recommendations. They posited that external factors should be incorporated into the performance indicators to be studied. This study has become important following occasional unsteadiness in the changes in stock prices and the connection it has with the performance in the Nigerian quoted Banks. Earnings per share only were picked as the financial performance indicator.

\section{Hypotheses}

H01: Earnings per share (EPS) does not positively and significantly influence the Market price of shares (MPS) of the Nigerian quoted banks.

H02: Inflation does not positively and significantly influence the MPS of the Nigerian quoted banks.

H03: Exchange rate does not positively and significantly influence the MPS of the Nigerian quoted banks.

H04: Interest rate does not positively and significantly influence the MPS of the Nigerian quoted banks.

\section{Literature Review}

Determinants of share prices were investigated by Kumar \& Hundal (1986). This study was embarked upon with the sole objective of determining the role of net sales per share, dividend per share retention ratio, net worth, growth in assets, and earning per share on changes in the share prices of companies. The result of the linear regression showed that EPS, DPS, asset growth, and retention ratio significantly and positively influence the company's share price; Moreover, DPS and EPS displayed a stronger influence on stock prices.

Moreover, there is a link in the study conducted by Dongwei (2003) with that of Kumar \& Hundai (1986). The study investigated the Chinese Capital Market and the result posited that stock price is influenced by EPS. Further, this study reveals that firms with disappointing EPS (group) will experience unfavorable downward pressure. It concluded that firms with higher EPS will experience an upward push in the share prices from when the earnings per share are announced.

Hartono (2004) evaluated DPS and EPS and the influence they bear on share price changes. The study showed that when a positive EPS is announced, it positively influences the share price; even when this announcement follows a negative one. Thus share price changes are caused by the information released per time the study concluded. A study on the Kuwait stock exchange by Al-Deehani (2005) investigated four variables namely: book value ratio (BVR), EPS, return on Equity (ROE), and DPS. He studied whether these variables influence the share prices of the stock market. The result showed that all the variables correlated positively and significantly with the share prices of the Kuwait stock exchange.

Also, Sharma (2011) assessed the relationship that could exist among EPS, dividend yield (DY), DPS, BVPS, and 
the Indian Stock Exchange share price. The study that covered 1993 through 1994 and 2008 - 2009 showed through the result displayed by correlation and a linear multiple regression model that EPS, BVP, and DPS meaningfully influenced the share prices. This was echoed as earlier stated by Nirmala, Sanju, Remachandran (2011) when they evaluated the Indian stock with a bid of determining the factors that influence their share prices. The result from the panel co-integration, correlation, and OLS revealed that PE ratio, dividends, and leverage significantly influence the changes in the share price for the sectors under consideration. Where PE ratio and DPS displayed a positive relationship with the share price while leverage bears a negative relation. But only in the auto sector was profitability influential on the share price.

483 firms from the Multex sector were evaluated to investigate the influence of certain variables on the change in the share price. This study was carried out by Myers \& Frank (2004). Their findings showed that Dividend payout ratio, and PE ratio influence share price changes. This study contrast that of Menaje (2012). All the variables such as DPS, Inflation, EPS show no influence at all on the share price. Only the 3-month T-bill rate exhibited an adverse influence on the changes in the share price.

Musa (2009) investigated dividend policy and whether it can be influenced by current earnings, previous dividend, cash flow, investment, and net current assets have a significant, combined, and separate impact. The study concluded that all the variables tested from selected Nigerian quoted firms show a positive influence on dividend policy. This is in line with the studies by Adelegan (2000), Oyejide (1976), and Izedonmi \& Eriki (1996).

An assessment of the Jakarta stock exchange to investigate if certain external factors influence share price was conducted by Aburime, (2009). The study covered 1993 - 1997. The study revealed a significant influence of the Exchange rate and the interest rate on the changes in the share price. In another study, the long and short-run influence of exchange rate on the changes in the share price was examined by Maku \& Atanda (2010). The study covered $2001-2008$. The result from the causality test carried out revealed that the exchange rate influences share price in a long run bi-directional term.

\section{Research Design}

This study adopts the ex-post factor research design. The ex-post factor gives the room for an empirical and logical solution to research issues. This can be seen in the adoption of time series design involving the dependent and the independent variables. (Asika, 2005) This research design establishes the connection between two variables (Onwureme, 2005). This research design has been used for notable studies such as This type of research design has been recently adopted by studies such as Agyire (2008) a study that was done in Ghana, Seyyed (2010) done in London, Al-Malkawi (2007), Kyereboah, Anthony, Uddin (2009), Ossisanwo \& Atanda (2012) done in Nigeria, Ike-Ekweremadu (2014) also carried out in Nigeria to mention a few.

\section{Population and Sample Size}

Twenty-one money deposit banks listed on the Nigerian stock exchange exist at the time of this study. Thirteen out of these were judgmentally selected. This selection was spurred by the fact that the selected banks made the list of the first one thousand banks by the World Bank ranking. This was published in the Bankers magazine of 2013, July as indicated in the work of Omoh, (2015). However, the bank was cut down to eleven due to the availability of data. The selected banks are: FCMB, First Bank, zenith bank, United Bank for Africa, Fidelity Bank, Ecobank Nigeria, Access Bank, Stanbic IBTC Holdings, Union Bank of Nigeria, Diamond Bank, and Guarantee Trust Bank

\section{Data Presentation}

The data presented below are that of the mean values of the entire selected banks.

Table 1

\begin{tabular}{llllll}
\hline YEAR & EPS & Inflation rate & interest rate & exchange rate & MPS \\
\hline 2000 & 1.49 & 6.94 & 9.58 & 102.11 & 7.24 \\
\hline 2001 & 1.48 & 18.87 & 8.18 & 112.35 & 8.79 \\
\hline 2002 & 1.38 & 12.88 & 8.10 & 126.40 & 7.71 \\
\hline 2003 & 1.62 & 14.03 & 6.50 & 136.50 & 8.19 \\
\hline 2004 & 1.30 & 15.00 & 5.48 & 132.35 & 10.53 \\
\hline
\end{tabular}




\begin{tabular}{llllll}
\hline 2005 & 1.02 & 17.86 & 7.42 & 128.50 & 10.65 \\
\hline 2006 & 1.09 & 8.22 & 7.16 & 126.50 & 13.46 \\
\hline 2007 & 1.17 & 5.41 & 6.65 & 116.30 & 25.67 \\
\hline 2008 & 1.72 & 11.58 & 3.51 & 130.75 & 24.54 \\
\hline 2009 & -0.03 & 12.54 & 5.07 & 149.78 & 10.88 \\
\hline 2010 & 0.57 & 13.72 & 11.06 & 148.67 & 9.26 \\
\hline 2011 & 0.49 & 10.84 & 10.32 & 156.20 & 10.27 \\
\hline 2012 & 1.35 & 12.22 & 8.39 & 155.27 & 9.85 \\
\hline 2013 & 1.31 & 8.48 & 8.78 & 155.20 & 12.16 \\
\hline 2014 & 1.44 & 8.06 & 7.21 & 167.50 & 12.87
\end{tabular}

Source: The Nigerian Stock Exchange Factbook and The Financial Statement of the sampled Banks

The data on the control variables are shown below:

Table 2

\begin{tabular}{lll}
\hline YEAR & PE & NAVPS \\
\hline 2000 & 5.04 & 11.16 \\
\hline 2001 & 8.08 & 5.06 \\
\hline 2002 & 10.65 & 5.30 \\
\hline 2003 & 6.35 & 5.43 \\
\hline 2004 & 8.59 & 4.94 \\
\hline 2005 & 16.31 & 4.82 \\
\hline 2006 & 17.65 & 6.00 \\
\hline 2007 & 22.77 & 6.40 \\
\hline 2008 & -23.52 & 10.24 \\
\hline 2009 & 13.70 & 7.49 \\
\hline 2010 & 11.42 & 5.68 \\
\hline 2011 & 11.32 & 7.70 \\
\hline 2012 & 11.38 & 8.44 \\
\hline 2013 & 11.65 & 9.68 \\
\hline 2014 & 13.27 & 10.11 \\
\hline
\end{tabular}

\subsection{Test of Reliability}

The unit root test was applied to the data to ensure a spurious-free result. Only EPS did not have a unit root issue. Others were detrended to solve this issue and a new variable generated. The descriptive data is shown below: 
Table 3. Descriptive statistics of operational variables

\begin{tabular}{lcllll}
\hline & EPS & INFLATION & INTEREST & EXCHANGE & MPS \\
\hline Mean & 1.160000 & 11.77667 & 7.560667 & 136.2920 & 12.13800 \\
Median & 1.310000 & 12.22000 & 7.420000 & 132.3500 & 10.53000 \\
Maximum & 1.720000 & 18.87000 & 11.06000 & 167.5000 & 25.67000 \\
Minimum & -0.030000 & 5.410000 & 3.510000 & 102.1100 & 7.240000 \\
Std. Dev. & 0.476535 & 3.879784 & 1.999716 & 18.64162 & 5.561293 \\
Skewness & -1.234706 & 0.167073 & -0.167425 & -0.091695 & 1.733620 \\
Kurtosis & 3.716981 & 2.266695 & 2.660477 & 2.089316 & 4.691872 \\
Jarque-Bera & 4.132536 & 0.405868 & 0.142125 & 0.539361 & 9.302619 \\
Probability & 0.006658 & 0.006332 & 0.931403 & 0.003623 & 0.009549 \\
Sum & 17.40000 & 176.6500 & 113.4100 & 2044.380 & 182.0700 \\
Sum Sq. Dev. & 3.179200 & 210.7381 & 55.98409 & 4865.141 & 432.9916 \\
Observations & 15 & 15 & 15 & 15 & \\
\hline
\end{tabular}

Source: Researcher's Computation using Eview 7

The NAVPS and PE ratio are control variables.

Table 4. Multicollinearity Result

Variance Inflation Factors

\begin{tabular}{llll}
\hline Variable & Coefficient & Uncentered & Centered \\
Variance & VIF & VIF \\
\hline C & 63.63265 & 69.75471 & NA \\
DEPS & 8.475197 & 3.151700 & 3.151582 \\
DNAVPS & 0.880418 & 4.896350 & 4.890921 \\
DPE & 0.020381 & 5.845490 & 5.837769 \\
DINFLATION & 0.111256 & 3.085747 & 3.084967 \\
DINTEREST & 0.355246 & 1.800275 & 1.789115 \\
DEXCHANGE & 0.019200 & 1.992608 & 1.533439 \\
CONTROL & 699.4204 & 70.83864 & 2.162830 \\
\hline
\end{tabular}

Source: Eview 7.1

Table 5. Result of the Heteroskedasticity Test: (Breusch-Pagan-Godfrey)

\begin{tabular}{llll}
\hline F-statistic & 1.500970 & Prob. F(7,6) & 0.3184 \\
Obs*R-squared & 8.911186 & Prob. Chi-Square(7) & 0.2591 \\
Scaled explained SS & 1.052767 & Prob. Chi-Square(7) & 0.9939 \\
\hline
\end{tabular}

Test Equation:

Dependent Variable: RESID ${ }^{\wedge} 2$

Method: Least Squares

\begin{tabular}{lllll}
\hline Variable & Coefficient & Std. Error & t-Statistic & Prob. \\
\hline C & 14.03541 & 12.76154 & 1.099821 & 0.3136 \\
DEPS & 4.246057 & 4.657342 & 0.911691 & 0.3971 \\
DNAVPS & 0.257498 & 1.501094 & 0.171540 & 0.8694 \\
DPE & 0.291190 & 0.228389 & 1.274977 & 0.2495
\end{tabular}




\section{DINFLATION \\ DINTEREST \\ DEXCHANGE \\ CONTROL}

R-squared

Adjusted R-squared

S.E. of regression

Sum squared resid

Log likelihood

F-statistic

Prob(F-statistic)

-0.016720
-1.845285
-0.342396
-24.76066
0.636513
0.212445
5.717162
196.1156
-38.34267
1.500970
0.318440

0.533611

0.953515

0.221676

42.30896

Mean dependent var

$-0.031333$

0.9760

$-1.935245$

0.1011

$-1.544578$

0.1734

0.5797

5.473407

S.D. dependent var

6.442289

Akaike info criterion

6.620381

Schwarz criterion

6.985557

Hannan-Quinn criter.

6.586578

Durbin-Watson stat

Source: Eview 7.1

The result of the heteroscedastic test as shown in Table 5 displayed a significant value of $26 \%$ which is higher than $5 \%$ we thus reject the alternative hypothesis and accept the null hypothesis. Therefore we can say that shows that the model is fit since it has no heteroscedasticity.

We hereby summarize the result of the multiple regression ran with eview 7.1.

\begin{tabular}{ll}
\hline EPS & $\mathbf{0 . 5 8 4 4}$ \\
& 0.3148 \\
& $(0.7686)^{* *}$ \\
\hline NAVPS & $\mathbf{- 1 . 9 7 8 1}$ \\
& -3.0874 \\
& $(0.0367)^{* *}$ \\
\hline PE & $\mathbf{- 0 . 3 7 6 1}$ \\
& -3.5698 \\
& $(0.0234)^{* *}$ \\
\hline INFLATION RATE & $\mathbf{- 0 . 8 1 5 2}$ \\
& -3.2701 \\
& $(0.0308)^{* *}$ \\
\hline INTEREST RATE & $\mathbf{- 0 . 8 0 4 4}$ \\
& -1.5966 \\
& $(0.1856)^{* *}$ \\
\hline EXCHANGE RATE & $\mathbf{- 0 . 4 1 0 0}$ \\
& -5.0887 \\
& $(0.0070)^{* *}$ \\
\hline
\end{tabular}

\subsection{Test of Hypothesis One}

$\mathrm{H}_{1}$ : Earnings per share (EPS) does not positively and significantly influence the Market price of shares (MPS) of the Nigerian quoted banks.

The P-value of 0.7686 is higher than 5\% therefore the null hypothesis is accepted. However, the model shows that EPS has a positive and insignificant influence on MPS. EPS coefficient is 0.58 as shown in the model below:

$$
\text { MPS }=14.0-1.98 \text { navps }-0.38 \text { pe }+0.58 \text { eps }-0.82 \text { inf }-0.80 \text { int }-0.41 \text { exch }
$$


The model above reveals that there is a 0.58 multiplying effect on a unit change of the share prices of the Nigerian quoted banks. We can therefore conclude that there is a positive but insignificant relationship between EPS and MPS. This however contradicts the findings of Ike-Ikweremadu (2014).

\subsection{Test of Hypothesis Two}

Inflation does not positively and significantly influence the MPS of the Nigerian quoted banks.

The P-value of 0.0308 is lower than 5\% signifying that there is a significant relationship between inflation and MPS of listed banks in Nigeria. This relationship is however a negative one as shown by the coefficient of -0.8152 . We can therefore assert that inflation has a significant but negative influence on the share prices of Nigerian listed banks.

\subsection{Test of Hypothesis Three}

The exchange rate does not positively and significantly influence the MPS of the Nigerian quoted banks.

The P-value of 0.0070 is less than 5\%, this means the exchange rate has a significant influence on MPS. Also, the coefficient of -5.0887 displays a negative influence. This means that for every one unit change in ordinary share price, the exchange rate has a multiplying effect of -5.01 . We can therefore conclude that the exchange rate has a significant but negative effect on the MPS of listed Nigerian banks.

\subsection{Test of Hypothesis Four}

The interest rate does not positively and significantly influence the MPS of the Nigerian quoted banks.

The p-value of 0.1856 is higher than 5\% therefore the null hypothesis is accepted while the alternative is rejected. However, the coefficient of -1.5966 shows that for every one unit change in the share price of Nigerian quoted banks, the interest rate has a multiplying effect of -1.5966 . This is a negative effect. We can therefore maintain that interest rate has an insignificant and negative effect on the share price of Nigerian quoted banks.

\subsection{Discussion of Findings}

We can truly relate to the reason why banks have a more volatile share price movement. The result differs from that of other sectors. EPS displayed a positive relationship with MPS which contrasts the findings of Ike Ikweremadu (2014). It also contradicts studies such as Kumar \& Hundal (1986). Hartono (2004), Sharma (2011), (Osisanwo \& Atanda, 2012; Obinwogu, 2012; Maku \& Atanda, 2009; Omole, 1999 and Ikoku, 2007). However, it agrees with Myers \& Frank (2004).

Inflation displayed a significant but negative influence on MPS. This is not good for the economy. Nigeria has lately experienced geometric inflation and that therefore accounts for the massive drop in banks share. This result however contradicts the study of Myers \& Frank (2004).

The exchange rate is also significant but negatively related to MPS. This is however not what the researchers expected. This indicates that the higher the exchange rate the lower the share price. This also accounts for the reason for a drastic reduction in the share price of Nigerian quoted banks. The exchange rate has been in drastic increase.

Interest rate is insignificant and also negatively related to MPS. This means that as the interest rate increases share price reduces; and vice versa. This may be a result of cause and effect. When banks increase interest rates lesser people go for loans and this causes a decreased turnover of loans obeying the economies of scale which in turn reduces performance. The lower the performance, the lower EPS which in turn discourages more investment in shares thereby causing the price of shares to drop.

\section{Conclusion}

The discussion of findings clearly shows that EPS has a positive effect on share price though it's insignificant. While the exchange rate has a significant relationship but negatively influencing the share price. This is the same with inflation. Inflation has a significant but negative influence on MPS. Interest rate also has a negative influence on MPS though it is insignificant.

\section{Recommendations}

Bank with a higher EPS will enjoy higher stock price though not a major shift. Banks should therefore endeavor to increase their EPS as much as possible in order to increase their stock price minimally. Also, the Nigerian Government should set up fiscal and monetary policies that would reduce inflation and devaluation of the Nigerian Naira as this will help increase the share prices of quoted banks in Nigeria. The interest rate should be reduced to a bearable level. This would increase the outflows of loans which would in turn increase performance and invariable increase the stock price. 


\section{References}

13 Nigerian banks make the top 1000 World Banks ranking. (n.d.). Retrieved September 16, 2015, from http://www.thebanker.com

Aburime, U. (2009, October). Determinants of bank profitability: company-level evidence from Nigeria. https://doi.org/10.2139/ssrn.1106825

Adelegan, O. J. (2000). An empirical analysis of the relationship between cash flows and dividend changes. A paper presented at the 23rd Annual Congress of the European Accounting Association (p. 5). Munich, Germany.

Aduda, J., Masila, J. M., \& Onsongo, E. N. (2012). The determinants of stock market development the case for the Nairobi Stock Exchange. International Journal of Humanities and Social Science, 109-190.

AL Taher, M. (2003). Profits distribution policy and its impact on the market stock price: an applied study on one sample of commercial banks at Amman security exchange, (22). Beit Lahem: Beit Lahem University Magazine.

Al-Deehani, T. M. (2005). Determinants of dividend policy: the case of Kuwait. The Arab Journal of Economic and Administrative Sciences, 19(2), 59-76. https://doi.org/10.1108/10264116200300006

Al-Omar, H., \& Almutairi. A. (2008). The relationship between the Kuwait banks share prices and their attributes. Kuwait: Fasial publishers.

Al-Shubiri. (2010). Analysis of the determinant of market stock price movement: an empirical study of Jordanian Commercial banks. International Journal of Business and Management. https://doi.org/10.5539/ijbm.v5n10p137

Brian, T. (2011). The meaning and concept of shares. Retrieved January 21, 2016, from http://accountlearning.blogspot.com.ng/2011/04/meaning-and-concept-of-equity-shares.html

Collins, J. (1957). How to study the behaviour of the bank. The Analyst Journal, 13(2), 109-113.

Dongwei, S. (2003). Stock price reactions to earnings announcements: evidence from Chinese markets. Review of Financial Economics, 87-89.

Echebarria-Miguel, M. C., \& Barrutia-Legarreta, J. M. (1999). De valor en banca (Creation of value in banking system). Informacion-Comercial-Espanola-Revista-de-Economia, (775).

Encarta. (2009). Retrieved from Encarta.afreecodec.com/encarta-dictionary-download

Godwin, C. O. (2010). Do emerging financial markets impact on investment opportunity set: a dynamic analysis of Nigerian case. Journal of Sustainable Development in Africa, 12(3), 1-11.

Hartono, J. (2004). The recency effect of accounting information. Gadjah Mada International Journal of Business, 6(1), 85-116. https://doi.org/10.22146/gamaijb.5536

ICAEW. (2000). Institute of chartered accountants in England and Wales, inside Out: reporting on shareholders Value. England: ICAEW Financial Reporting Committee.

Ike_Ekweremadu, N. B. (2014). Corporate financial indicators and movements in equity share prices: evidence from Nigeria brewery industry. DSpace JSPUI. Retrieved 19th Oct. 2016, from http://hdl.handle.net/123456789/760

Ikoku, A. E. (2007, March 3). The impact of inflation on stock market returns in Nigeria. Business Day Newspaper.

Inyiama, O, I., \& Chike, N. (2014). Macroeconomic variables and shares price movement in Nigeria brewery industry: evidence from Nigerian Breweries Plc. European Journal of Accounting Auditing and Finance Research, 19-31.

Izedonmi, O. I. F., \& Eriki, P. O. (1996). Determinants of dividend policy in publicly quoted companies. ICAN News.

Jimoh, E. O. (2009). Determinants of stock prices in the capital market. Unpublished dissertation, Department Of Banking And Finance, Faculty Of Management Sciences, Olabisi Onabanjo University, Ago-Iwoye, Nigeria.

Kang, J., \& Stulz, R. (1997). Is there a home bias? an analysis of foreign portfolio equity ownership In Japan. Journals of Financial Economics. https://doi.org/10.1016/S0304-405X(97)00023-8

Koller, T. (1994). What is value-based management? (3 ed.). The Mckinsey Quarterly.

Kumar, \& Hundal. (1986). Stock market integration examining linkages between India and selected Asian markets. Foreign Trade Review, 45, 3-18. https://doi.org/10.1177/0015732515100301 
Mackinlay. (2007). Stock market prices do not follow random walk: Evidence from a simple specification test: Massachusetts. American Finance Association.

Maku, O. E., \& Atanda, A. A. (2010). Determinants of stock market performance in Nigeria: long-run analysis. Datatric Research Consulting, Nigeria, Globafrique Consulting, U.K, 1-16.

Malhotra, N. (2013). Determinants of stock prices: empirical evidence from NSE 100 companies. International Journal of Research in Management \& Technology, 3(3), 86-95.

Malhotra. M., \& Prakash. N. (2001). Determinants of the market price of A-group and B-group shares. The ICFAI Journal of Applied Finance, 7(3), 45-53.

Menaje, J. P. (2012). Impact of selected accounting and economic variables on the share price of publicly listed banks in the Philippines from 2002-2008. DLSU Business \& Economics Review, 22(1), 35-62.

Moore, A. B. (1962). A statistical analysis of common stock prices. Unpublished Doctoral Dissertation, University of Chicago.

Myers, M., \& Frank, B. (2004). The determinants of corporate dividend policy. Academy of Accounting and Financial Studies Journal, 8(3), 17-28.

Nirmala, P. S., Sanju, P. S., \& Remachandran, M. (2011). Determinants of share price in India. Journal of Emerging Trends in Economics and Management Sciences, 2(2), 124-130.

Nwokoma, N. I. (2002). Stock market performance and macroeconomics indicators nexus in Nigeria: an empirical investigation Nigerian. Journals of Economics and Social Studies, 119.

Omole, D. A. (1999). Financial depending on and stock market development in Nigeria. Nigerian Institute of Social and Economic Research (NISER). NIDER Monograph Series (15).

Omoyiola, A., \& Adeolu, M. (2011). Effects of organizational performance on sharePrice: an empirical study of the top-performing manufacturing Listed on the Nigerian Stock Exchange. Scottish Journal of Arts, Social Sciences and Scientific Studies, 15-25.

Onoh, J. (2002). Dynamics of money, banking, and financing in Nigeria-an emerging market. Calabar: Astra Meridian Publishers.

Osisanwo, B. G., \& Atanda, A. A. (2012). Determinants of stock market return in Nigeria: A time series analysis. African Journal of Scientific Research, 9(1), 478-496.

Oyejide, T. A. (1976). Company dividend policy in Nigeria: an empirical analysis. Nigerian Journal of Economics \& Social Studies, 18(2), 179.

Rahman, M., Baten, A., Udden, B., \& Jubayer, M. (2006). Fame-franchise CAPN: an empirical investigation on DSE. Tacrendi Press.

Sharma, S. (2011). Determinants of equity share prices in India. Journal of Arts, Science \& Commerce, 2(4), 52-60.

Shukairi, N. M., Waleed Al Safi, AbdulBaset H., \& Marwan, M. A. (2012). The relationship between inflation and stock prices. IJRRAS, 47.

Stanlake, G. (1993). Introductory economics. Longman House, Essex.

Valix, C., \& Peralta, J. (2007). Financial Accounting (2007 ed., Vol. 2). Manila: GIC Enterprises \& Co., Inc.

Victor, A., Jonathan, E., \& Anthony, O. (2013). Determinants of stock price movement In Nigeria: Evidence from monetary variables. Journal of Economics and Sustainable Development, 4(14), 87-103.

Zahra, L., \& Mousa, A. (2004). The impact of dividend poilicy on stock price volatility in the Tehran Stock Exhange. Kuwait Chapter of Arabian Journal of Business and Management Review, 3(10), 273-283. https://doi.org/10.12816/0018408

\section{Copyrights}

Copyright for this article is retained by the author(s), with first publication rights granted to the journal.

This is an open-access article distributed under the terms and conditions of the Creative Commons Attribution license (http://creativecommons.org/licenses/by/4.0/). 